\title{
Androgen induces differentiation of a human papillomavirus 16 E6/E7 immortalized prostate epithelial cell line
}

\author{
M T Ling, K W Chan and C K Choo \\ Department of Pathology, The University of Hong Kong, Hong Kong \\ (Requests for offprints should be addressed to K W Chan, Department of Pathology, The University of Hong Kong, Queen Mary Hospital Compound, \\ Hong Kong; Email: hrmtckw@hkucc.hku.hk)
}

\begin{abstract}
Androgen signaling is crucial for the growth and development, as well as for tumorigenesis of the prostate. However, many of the prostate epithelial cell lines developed previously, either normal or tumorigenic, do not express androgen receptor (AR) or respond to androgen. In order to advance our understanding on how androgen signaling regulates the growth and the differentiation status, and affects tumorigenicity of the epithelial cell, we performed experiments on $\mathrm{HPr}-1$, a prostate cell line recently immortalized from normal human prostate epithelial cells. In the present study, AR was stably transfected into
\end{abstract}

HPr-1 cells by replication-defective retrovirus. Treatment of HPr-1AR cells with androgen resulted in cell differentiation and growth retardation accompanied with up-regulation of cytokeratins $\mathrm{K} 8$ and $\mathrm{K} 18$, prostate specific antigen, p21 and p27, and down-regulation of c-myc, bcl-2 and telomerase activity. Our results suggest that androgen promotes the process of differentiation in a human papillomavirus 16 E6/E7 immortalized prostate epithelial cell line which may reflect the normal effects of androgen on prostate cells.

Journal of Endocrinology (2001) 170, 287-296

\section{Introduction}

Although androgen is known to be important for the growth and development of the prostate, its action is still not fully known. Removal of androgen results in rapid degeneration of the normal and neoplastic prostate cells, as reflected by prostate cancer patients after androgen ablation therapy. Yet among these patients, many of them progress to an androgen independent stage after the therapy, where the tumor starts to re-grow in the absence of androgen (Scott et al. 1980). A better understanding of the precise action of androgen on the normal and neoplastic prostate cells is necessary in order to find out how androgen independent prostate cancer may arise and to improve the treatment for prostate cancer.

In the prostate, androgen receptor (AR) is mainly expressed by epithelial and smooth muscle cells (Chodak et al. 1992). During the degeneration of the prostate after androgen ablation, epithelial cells are the major cell type that undergo apoptosis (Berges et al. 1993), suggesting that the epithelial cell is highly dependent on androgen for survival. Also, the growth of several prostate epithelial cell lines, such as LNCaP (Horoszewicz et al. 1983), NRP-152 (Danielpour et al. 1994) and RWPE-1 (Bello et al. 1997), are stimulated by androgen. However, many studies have also shown that the growth of immortalized cell lines or even primary cultures derived from prostate epithelium are not stimulated by androgen (McKeehan et al. 1984,
Rundlett et al. 1992, Grant et al. 1996, Berthon et al. 1997). Meanwhile, the study by Cunha \& Lung (1978) has demonstrated that urogenital sinus epithelium from testicular feminizing mice, which lacks AR expression, can still develop into a prostate-like structure but only when combined with urogenital sinus mesenchyme that expresses AR. This suggests that androgen acts indirectly through the mesenchyme to stimulate the growth of the epithelial cell. The androgen-signaling cascade in epithelial cells may thus have functions other than growth stimulation.

Previously, Heisler et al. (1997) have shown that androgen induces growth arrest and apoptosis in PC-3 cells ectopically transfected with the AR gene. This seems to contradict the generally perceived effect of androgen on prostate epithelial cells. Since PC-3 cells were derived from tumor at an advanced stage, the observation may not reflect the normal effect of androgen on epithelial cells. In this study, we employed a prostate epithelial cell line, HPr-1, for the study of direct androgenic effects on epithelial cells.

The cell line was previously immortalized in our laboratory by the introduction of HPV16 E6/E7 (Choo et al. 1999). It was found to be non-tumorigenic but does not express AR and does not respond to androgen stimulation. The reason for the lack of AR expression in HPr-1 cells is uncertain but it is likely to be due to the incomplete microenvironment of the culturing systems. We had the 
AR gene expressed in HPr-1 cells by retroviral transduction of a wild type AR cDNA. The resultant cell line, HPr-1AR, was used as a model for the investigation of the effects of androgen on prostate epithelial cells. Since $\mathrm{HPr}-1 \mathrm{AR}$ is non-tumorigenic and morphologically resembles normal prostate epithelial cells, our findings probably reflect the effect of androgen on normal epithelial cells of the prostate.

\section{Materials and Methods}

\section{Cell culture}

HPr-1 and HPr-1AR cells were maintained in keratinocyte serum free medium (SFM; Gibco, Gaithersburg, MA, USA) supplemented with penicillin $\mathrm{G}(100 \mathrm{U} / \mathrm{ml})$, streptomycin $(100 \mu \mathrm{g} / \mathrm{ml})$ and gentamicin $(50 \mu \mathrm{g} / \mathrm{ml})$. For experiments, the cells were grown in RPMI medium supplemented with 10\% charcoal-dextran-treated fetal bovine serum (charcoal-dextran-treatment removed lipids and lipid soluble steroids including androgen) and various doses $(0 \cdot 1$ to $100 \mathrm{nM})$ of mibolerone (a non-hydrolysable androgen analog) dissolved in ethanol or an equivalent volume of the vehicle. The concentration of mibolerone was found to be optimum at $5 \mathrm{nM}$ and this concentration was used for the rest of the study.

\section{Generation of sub-cell line $\mathrm{HPr}-1 A R$}

The retroviral vector $\mathrm{pBabe}-\mathrm{AR}$ was generated by inserting the full-length human $\mathrm{AR}$ gene into the $\mathrm{pBabe}$ vector (a generous gift from Dr Scott Lowe at Cold Spring Harbor Laboratory, Cold Spring Harbor, NY, USA). Transfection of the packaging cell line PA317 (Miller \& Buttimore 1986) with pBabe-AR was carried out with the Fugene 6 transfection reagent (Roche Molecular Biochemicals, Basel, Switzerland), following the protocol provided by the manufacturer. The supernatant of the transfected pBabe-AR PA317 cells was collected $72 \mathrm{~h}$ post transfection, and used to infect HPr-1 cells in the presence of $8 \mu \mathrm{g} / \mathrm{ml}$ polybrene. The infected $\mathrm{HPr}-1$ cells were selected with $2 \mu \mathrm{g} / \mathrm{ml}$ puromycin for one week. Positive cells were expanded and further selected with $4 \mu \mathrm{g} / \mathrm{ml}$ puromycin to yield a stably AR transduced HPr-1AR sub-line.

\section{Growth characteristics of HPr-1 and HPr-1AR cell lines}

For mibolerone dose-response experiments, HPr-1 or HPr-1AR cells were seeded at $200000 / 10 \mathrm{~cm}^{2}$, grown in RPMI medium containing 10\% charcoal-dextran-stripped fetal bovine serum (FBS) supplemented with either various concentrations of mibolerone or vehicle alone. The cells were harvested and counted after $72 \mathrm{~h}$. For the growth curve experiment, the cells were seeded at
100 000/10 $\mathrm{cm}^{2}$ in SFM and switched to RPMI medium supplemented with 10\% charcoal-dextran-stripped FBS with $5 \mathrm{nM}$ mibolerone or with vehicle alone $48 \mathrm{~h}$ after seeding. At daily intervals (for consecutive 4 days), the cells were trypsinized, washed with PBS, and counted in triplicate with a hemacytometer. Phase contrast microscopy was carried out using a Nikon Phase Contrast -2 microscope at $200 \times$ magnification at the end of the experiment.

\section{Gene expression pattern of HPr-1 and HPr-1AR cells}

Test cells were first washed with PBS and then lysed with RIPA buffer (PBS, 1\% Nonidet P-40, 0.5\% sodium deoxycholate, $0 \cdot 1 \%$ SDS, $10 \mu \mathrm{g} / \mathrm{ml}$ phenylmethylsulfonyl fluoride (PMSF), $20 \mu \mathrm{g} / \mathrm{ml}$ aprotinin, $10 \mu \mathrm{g} / \mathrm{ml}$ leupeptin, $100 \mathrm{mM}$ sodium orthovanadate). The cells were collected by a rubber policeman and passed through a 21-gauge syringe. After incubating on ice for $1 \mathrm{~h}$, the sample was centrifuged at 13000 r.p.m. for $30 \mathrm{~min}$. The protein content of the supernatant was measured using the DC Protein Assay kit (Bio-Rad, Hercules, CA, USA). Protein samples were boiled in $6 \times$ sample buffer $(3.5 \mathrm{mM}$ Tris- $\mathrm{HCl}(\mathrm{pH}$ 6.8), 30\% glycerol, 10\% SDS, 24\% 2 -mercaptoethanol, $0 \cdot 12 \mathrm{mg} / \mathrm{ml}$ bromophenol blue). Cell lysate $(20 \mu \mathrm{g})$ was subjected to SDS-PAGE and transferred to PVDF membranes. The membranes were blocked with $10 \%$ skim milk in TBST $(20 \mathrm{mM}$ Tris $\mathrm{HCl}, 137 \mathrm{mM}$ $\mathrm{NaCl}, 0 \cdot 1 \%$ Tween 20), washed with TBST and probed with mouse monoclonal antibodies against AR, prostate specific antigen (PSA), p21, p27, bcl-2, bax (Pharmingen, San Diego, CA, USA), c-myc, cytokeratin K18 (Santa Cruz, San Diego, CA, USA) or cytokeratin K8 (Sanbio, San Diego, CA, USA). The membranes were washed with TBST and covered with horseradish peroxidaseconjugated secondary antibodies (Amersham International, Amersham, Bucks, UK) at room temperature for $1 \mathrm{~h}$, washed again with TBST and visualized by enhanced chemiluminescence (ECL) according to the manufacturer's recommendations (Amersham International). The secondary antibody was included in the ECL kit. The results of the Western blotting on AR, cytokeratin 8 and 18 were analyzed by densitometer. The presence of PSA was also tested with ELISA according to the manufacturer's protocol (Abbott Laboratories, Abbott Park, IL, USA).

\section{Luciferase assay}

Cells $(60 \%$ confluent $)$ in $25-\mathrm{cm}^{2}$ flasks were transfected with the plasmid pMAMneoLuc (Clontech, Palo Alto, CA, USA) using the Fugene 6 transfection reagent. The pMAMneoLuc contains a luciferase reporter gene under the transcriptional control of the mouse mammary tumor virus (MMTV) promoter, which contains androgen responsive elements. In cells expressing functional AR, treatment with exogenous androgen leads to nuclear 
localization of $A R$ and therefore up-regulation of the luciferase gene transcription. After $24 \mathrm{~h}$, the transfected cells were trypsinized and split into two separate 6-well clustered dishes. Mibolerone was added to one group and vehicle alone to the other. Cell lysate was extracted $72 \mathrm{~h}$ after transfection and the luciferase activity in the cell lysate was assayed using the luciferase assay kit from Tropix (Bedford, MA, USA), according to the protocol provided by the manufacturer. Each treatment was performed in triplicate.

\section{Expression of the PSA gene}

The expression of the PSA gene in HPr-1 and HPr-1AR cells was studied by reverse transcription-polymerase chain reaction (RT-PCR). In brief, HPr-1 and HP-1AR cells were treated with mibolerone or vehicle for six days. Total RNA was isolated by the Trizol reagent with procedures described by the manufacturer and $1 \mu \mathrm{g}$ of the total RNA was reverse transcribed with the Expand reverse transcriptase (Roche Molecular Biochemicals) and amplified with a set of PSA specific primers (sense: $5^{\prime}-$ GCC TCT CGT GGC AGG GCA GTC-3', antisense: 5'-CAT CAC CTG GCC TGA GGA ATC- $3^{\prime}$ ). An initial denaturation at $95{ }^{\circ} \mathrm{C}$ was followed by 30 cycles of PCR $\left(94^{\circ} \mathrm{C}\right.$ for $30 \mathrm{~s}, 68^{\circ} \mathrm{C}$ for $1 \mathrm{~min}$ ), and a final extension at $72{ }^{\circ} \mathrm{C}$ for $5 \mathrm{~min}$. The $\beta$-actin gene was amplified by a pair of primers (sense: $5^{\prime}$-GTC GGG CGC CCC AGG CAC CA-3', antisense: 5'-CTC CTT AAT GTC ACG CAC GAT TTC-3') to control for the amount of mRNA and for integrity. The PCR conditions are similar to those for PSA. PCR products were electrophoresed in $2 \%$ agarose gels, transferred onto Hybond-N membrane (Amersham International) and hybridized with ${ }^{32} \mathrm{P}$-end-labeled PSA (5'-AGC TAC CCA CTG CAT CAG GA-3') and $\beta$-actin (5'-AAT CCT TCT GAC CCA TGC CCA CCA TCA-3') oligonucletotide probes. The hybridization signal was visualized after autoradiography.

\section{Telomerase activity}

Telomerase activity was assayed with the Telomeric Repeat Amplification Protocol (TRAP) (Intergen, Purchase, NY, USA). Briefly, the assay was carried out in a $50 \mu \mathrm{l}$ reaction with $2 \mu \mathrm{l}$ cell extract $(0 \cdot 1,0 \cdot 3$ or $1 \cdot 0 \mu \mathrm{g}$ protein), $0 \cdot 1 \mathrm{mg}$ of each primer $\left(5^{\prime}\right.$-CCC TTA CCC TTA CCC TTA CCC TAA- $3^{\prime}$ and $5^{\prime}$-AAT CCG TCG AGC AGA GTT-3'), 20 mM Tris- $\mathrm{HCl}(\mathrm{pH} 8 \cdot 3$ ), $1.5 \mathrm{mM} \mathrm{MgCl}$, $63 \mathrm{mM} \mathrm{KCl}, 0 \cdot 005 \%$ Tween 20, 1.0 mM EGTA, $0 \cdot 1 \mathrm{mg} /$ $\mathrm{ml}$ BSA, $0.25 \mathrm{mM}$ dNTP, $1 \mathrm{U}$ Taq polymerase and $0.4 \mathrm{ml}$ $\left[\alpha_{-}{ }^{32} \mathrm{P}\right] \mathrm{dCTP}(3000 \mathrm{Ci} / \mathrm{mmol})$. PCR amplification was performed for 25 cycles at $94{ }^{\circ} \mathrm{C}, 50{ }^{\circ} \mathrm{C}$ and $72{ }^{\circ} \mathrm{C}, 30 \mathrm{~s}$ each. Cell extracts incubated with RNase for $30 \mathrm{~min}$ at $37^{\circ} \mathrm{C}$ were included as negative controls.

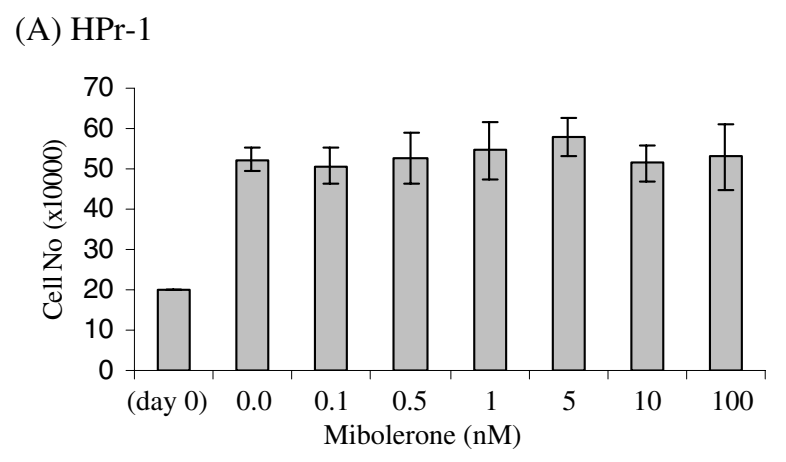

(B) HPr-1AR

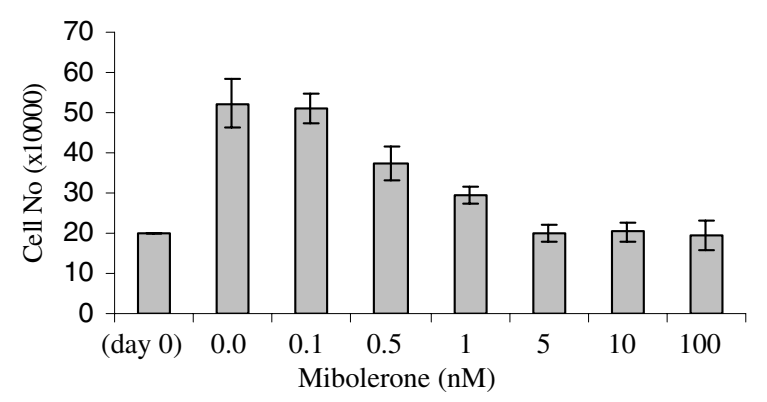

Figure 1 Dose-response assay for HPr-1 and HPr-1AR cells in response to mibolerone. HPr-1 and HPr-1AR cells were treated with vehicle alone or with various concentrations of mibolerone $\mathrm{Mb}$ and the number of cells was counted after $72 \mathrm{~h}$ of treatment. The total cell number is shown as an average of 3 replicates. Proliferation of HPr-1AR cells started to decline at $0 \cdot 1 \mathrm{nM} \mathrm{Mb}$ and the maximum effect was observed at $5 \mathrm{nM} \mathrm{Mb}$. Proliferation of $\mathrm{HPr}-1$ cells was not affected by $\mathrm{Mb}$ at the concentrations used.

\section{Results}

Growth characteristics of the $H P r-1$ and $H P r-1 A R$ cell lines

Proliferation of HPr-1 and HPr-1AR cells was tested with various concentrations of mibolerone for a period of 3 days (Fig. 1). Minor attenuation ( 20\%) of the proliferation of HPr-1AR cells was seen with $0.5 \mathrm{nM}$ mibolerone, and the effect was most pronounced at $5 \mathrm{nM}$. No further growth inhibition was observed with mibolerone concentrations higher than $5 \mathrm{nM}$. Therefore, $5 \mathrm{nM}$ mibolerone were used in the rest of this study. Growth of HPr-1 cells was not affected by the presence of mibolerone at the dose range tested, suggesting that the cells did not respond to mibolerone treatment. In time-course experiments (Fig. 2), inhibition of proliferation of $\mathrm{HPr}-1 \mathrm{AR}$ cells by mibolerone was evident at $48 \mathrm{~h}$ and most cells were growth arrested at $72 \mathrm{~h}$. Growth regulation of $\mathrm{HPr}-1 \mathrm{AR}$ by mibolerone was completely abolished by pretreating the cells with $10 \mu \mathrm{M}$ hydroxyflutamide (an androgen antagonist) for $20 \mathrm{~h}$ before the addition of mibolerone. 


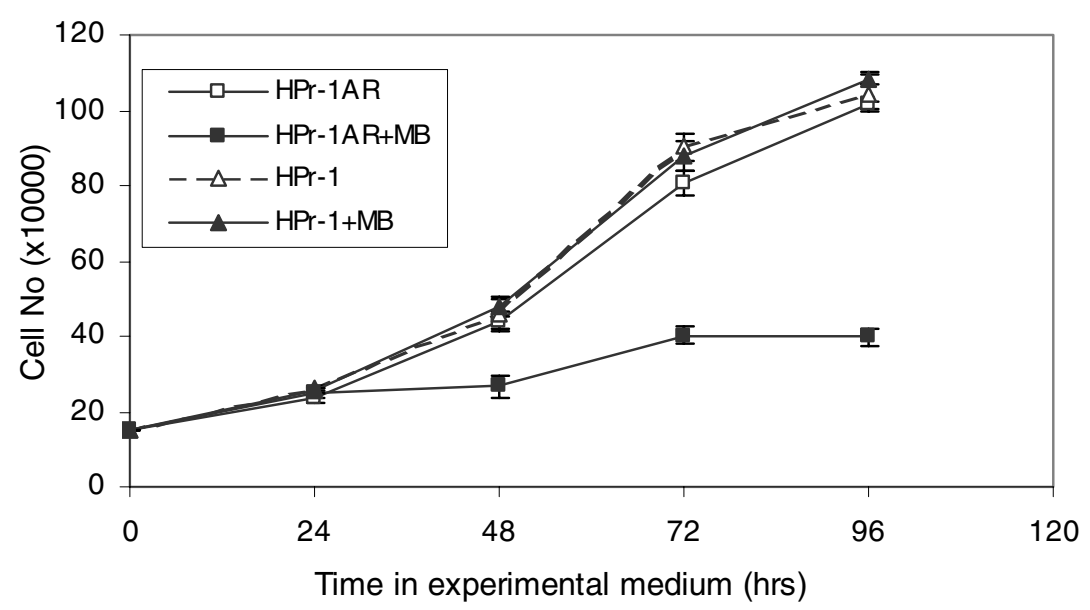

Figure 2 Proliferation of HPr-1 and HPr-1AR cells in response to mibolerone. HPr-1 and $\mathrm{HPr}-1 \mathrm{AR}$ cells were treated with either mibolerone (MB; $5 \mathrm{nM}$ ) or vehicle and the number of cells was counted every $24 \mathrm{~h}$. The total cell number is shown at each time interval. The growth rate of HPr-1AR cells declined $48 \mathrm{~h}$ after androgen treatment, while HPr-1AR cells grown in the absence of MB and HPr-1 cells (irrespective of the addition of MB) continued to proliferate throughout the experiment.

\section{(A)}

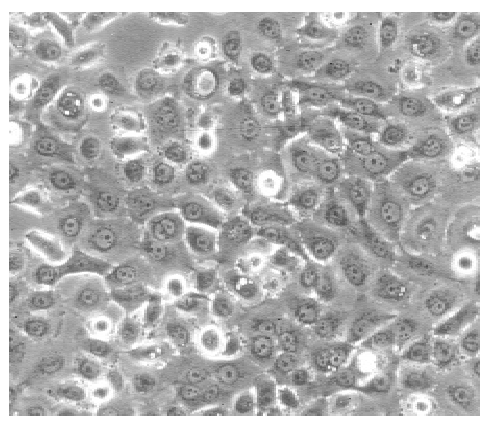

(B)

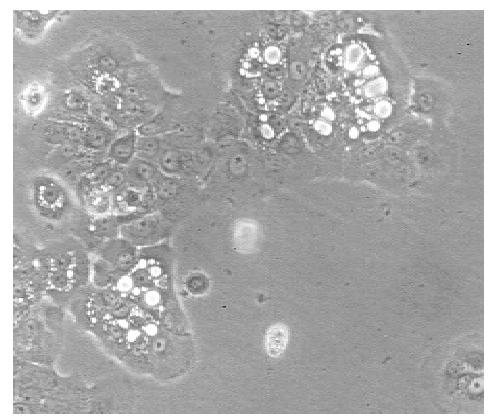

(C)

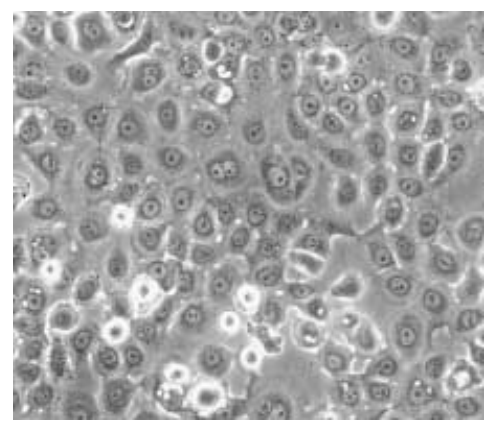

Figure 3 Cell morphology under phase contrast microscopy. HPr-1AR cells treated with ethanol (A) or androgen (B) for $72 \mathrm{~h}$. (A) HPr-1AR cells treated with ethanol grew to $100 \%$ confluence at $72 \mathrm{~h}$. (B) In the presence of androgen, HPr-1AR cells demonstrated differentiated morphology and displayed growth retardation. Androgen had no effect on the morphology of HPr-1 cells (data not shown). In addition, the morphological changes induced by mibolerone in HPr-1AR cells were reversed by the addition of $10 \mathrm{mM}$ hydroxyflutamide (C).

Figure 3 shows the morphology of HPr-1 and $\mathrm{HPr}-$ $1 \mathrm{AR}$ cells in the presence and absence of mibolerone. As indicated in the figure, mibolerone treatment induced striking morphological changes in HPr-1AR. The morphology of HPr-1AR cells became differentiated when compared with the untreated $\mathrm{HPr}-1 \mathrm{AR}$ cells and persisted as colonies which did not grow to confluence at the time when the untreated cells reached $100 \%$ confluence. This phenomenon was absent in $\mathrm{HPr}-1$ cells treated with mibolerone or in mibolerone-treated $\mathrm{HPr}-1 \mathrm{AR}$ cells blocked with $10 \mathrm{mM}$ hydroxyflutamide, suggesting that the morphological alterations and growth inhibition of HPr-1AR cells were induced by the androgen-signaling cascade.
Expression of functional AR in HPr-1 and HPr-1AR cells

In order to verify that the differential effects of mibolerone on HPr-1 and HPr-1AR cell lines were due to expression of functional AR, Western blot of AR was performed. No AR was detected in the parental HPr-1 cell line, but in the HPr-1AR sub-cell line a $110 \mathrm{kDa}$ band was visualized by Western blotting of AR (Fig. 4). LNCaP, a lymph node metastatic prostate cell line expressing AR, was used as a positive control for the blotting. The level of AR in HPr-1AR cells was about threefold higher than in $\mathrm{LNCaP}$ cells. In functional assays of the AR with pMAMneoLuc plasmid, mibolerone induced a 15-fold increase in luciferase activity 


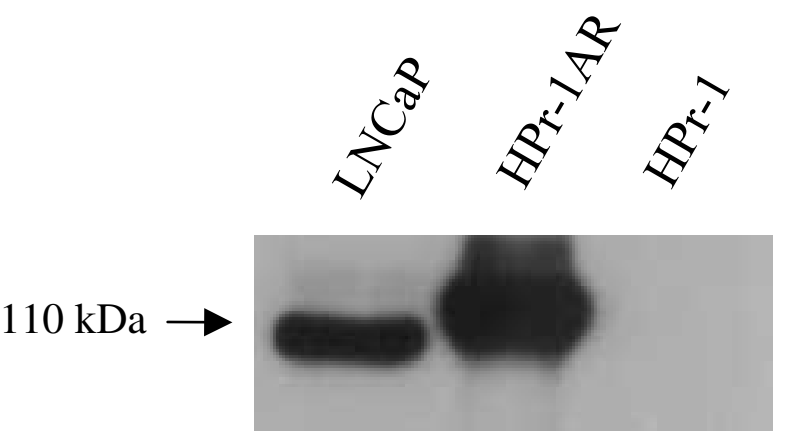

Figure 4 Western blot analysis of AR expression in LNCaP, $\mathrm{HPr}-1 \mathrm{AR}$ and $\mathrm{HPr}-1$ cells. Twenty milligrams whole cell lysate were loaded for each sample. LNCaP, an AR positive prostate cell line was included as control. HPr-1AR cells expressed AR at a level that was $300 \%$ higher than LNCaP cells. HPr-1 cells were negative for AR expression.

in $\mathrm{HPr}-1 \mathrm{AR}$ cells, confirming that the expressed AR was functional. The parental HPr-1 cells were not responsive to mibolerone (Fig. 5).

Expression pattern of the differentiation-related genes in $H P r-1$ and $H P r-1 A R$ cells

To determine if the growth arrest observed in HPr-1AR cells after mibolerone treatment was due to induction of cellular differentiation, the expression of cytokeratins $\mathrm{K} 8$ and $\mathrm{K} 18$, which are up-regulated in prostate epithelial cells during differentiation (Sherwood et al. 1989, 1991), was studied by Western analysis. Immunoreactive bands representing the cytokeratins K8 and K18 respectively, were detected in both HPr-1 and HPr-1AR cells (Fig. 6). After mibolerone treatment, the protein levels of cytokeratins $\mathrm{K} 8$ and $\mathrm{K} 18$ in $\mathrm{HPr}-1 \mathrm{AR}$ cells were found to have increased by around 6- and 8-fold respectively when compared with the expression in untreated cells, while the cytokeratin expression of $\mathrm{HPr}-1$ cells was unchanged following mibolerone treatment.

In addition, the expression of $\mathrm{p} 21$ and $\mathrm{p} 27$, which are also up-regulated in differentiating epithelial cells (Tian \& Quaroni 1999), was also found to be increased in HPr-1AR cells treated with mibolerone. The level of both proteins increased substantially after $24 \mathrm{~h}$ of androgen treatment and the level persisted throughout the next 48 h. Finally, c-myc and bcl-2, which are down-regulated in terminal differentiated cells (Grolli et al. 1997), were also shown to decrease after mibolerone treatment in HPr-1AR cells (Fig. 7). As shown in the figure, the down-regulation of c-myc was rapid and drastic, while an observable decrease in bcl-2 could only be found after $72 \mathrm{~h}$ of androgen treatment. The expression of bax was not affected by androgen in either HPr-1 and HPr-1AR cells.

PSA is an important marker for prostate cells and is highly expressed in terminally differentiated epithelial cells

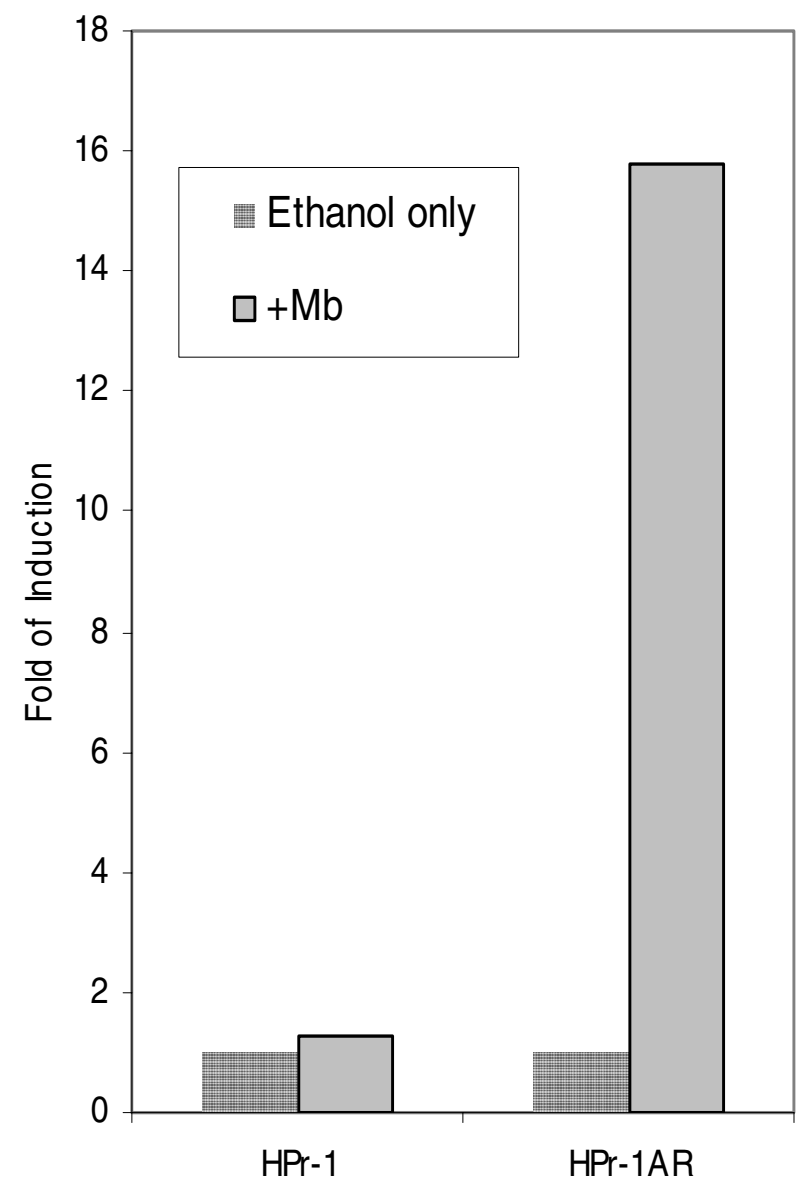

Figure 5 Luciferase activity assay. HPr-1 and HPr-1AR cells transfected with pMAMneoLuc plasmid were treated with $5 \mathrm{nM}$ mibolerone $(\mathrm{Mb})$ in ethanol or with ethanol alone. Cells were then lysed and assayed for luciferase activity. Results are represented as the level of luciferase induction by androgen compared with normal $(100 \%)$. Androgen increased luciferase activity (greater than 15-fold) in HPr-1AR cells but had no effect in HPr-1 cells.

(Coffey 1993). However, we were unable to detect expression of PSA in HPr-1 or HPr-1AR cells. To determine if the absence of PSA expression was due to inactive transcription or transcript translation, we looked for PSA mRNA by RT-PCR. In HPr-1AR cells, PSA mRNA was not detected after the first day of androgen treatment. After three days of treatment, PSA mRNA started to appear and almost doubled its level at day six of treatment (Fig. 8). No PSA mRNA could be detected in HPr-1 after six days of androgen treatment or in HPr-1AR treated with vehicle for six days. The results indicated that PSA transcript was induced in HPr-1AR cells by androgen.

\section{Telomerase activities}

Decrease in telomerase activity upon induction of differentiation has been reported in a number of immortalized 


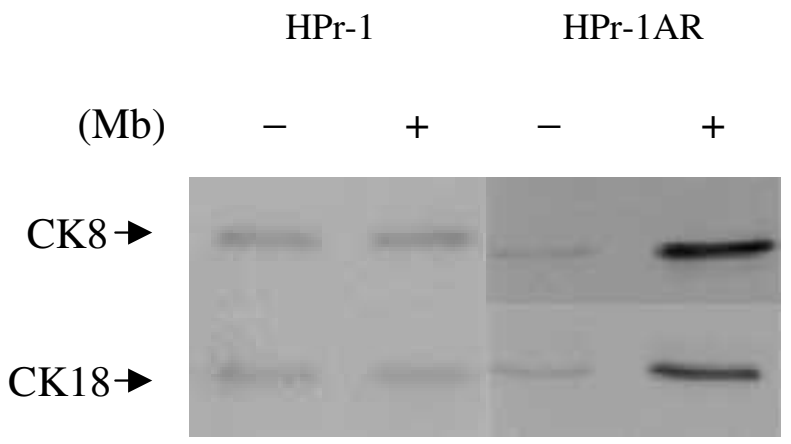

Figure 6 Expression of cytokeratins (C) K8 and K18. Total cell lysates of HPr-1AR cells treated with mibolerone $(\mathrm{Mb})$ or ethanol for 6 days were subjected to Western blot analysis for protein levels of CK8 or CK18. $\beta$-Actin was added as loading control (not shown). Both of the differentiation-specific cytokeratins were found to be up-regulated after the treatment.

cell lines (Sharma et al. 1995), as well as in some carcinoma cell lines (Savoysky et al. 1996). To further demonstrate that HPr-1AR cells were undergoing differentiation, telomerase activity in $\mathrm{HPr}-1 \mathrm{AR}$ cells grown in the presence or absence of androgen was determined by the TRAP assay. As demonstrated in Fig. 9, telomerase activity of HPr-1AR cells was unchanged after six days of mibolerone treatment, but was then sharply down-regulated at day 9 of the treatment. In non-treated HPr-1AR cells, telomerase activity remained unchanged.

\section{Discussion}

As described previously, the HPr-1 cells we used in our study neither express AR nor respond to androgen. Similarly, several of the established prostate epithelial cell lines, such as BPH-1 (Hayward et al. 1995), PC-3 (Kaighn et al. 1979) or DU145 (Mickey et al. 1980) were also found to be AR negative. Previously, Bello et al. (1997) had established a human prostate epithelial cell, RWPE-1, which represented one of the few immortalized non-

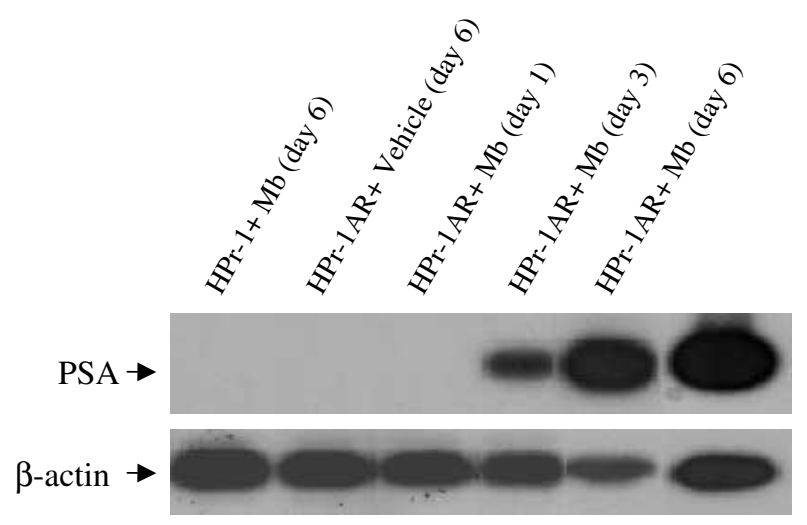

Figure 8 RT-PCR for PSA. RNA was extracted from HPr-1 or $\mathrm{HPr}-1 \mathrm{AR}$ cells treated with $5 \mathrm{nM}$ mibolerone $(\mathrm{Mb})$ or vehicle. RNA of LNCaP (shown as the last lane) served as a positive control. One microgram of each sample was subjected to RT-PCR for the transcripts of PSA or $\beta$-actin. The RT-PCR products were probed with ${ }^{32}$ P-labeled oligo-nucleotides specific for PSA or $\beta$-actin. Expression of the PSA transcript showed a marked increase after androgen treatment.

tumorigenic cell lines showing AR expression and growth stimulation by androgen. Since HPr-1 and RWPE-1 were both immortalized by human papilloma virus, the difference in $\mathrm{AR}$ expression and androgen responsiveness is unlikely to be due to the variation in immortalization method. Meanwhile, the results from RT-PCR and Western blotting of AR (data not shown) have shown that AR was absent in both the parental and HPr-1 cells, suggesting that the lack of AR expression did not result from immortalization. The study by Blanchere et al. (1998) demonstrated that stromal-epithelial interaction is important for optimal expression of AR. The lack of stromalepithelial interaction in culture systems may partly explain the absence of AR in $\mathrm{HPr}-1$ cells. Meanwhile, it is known that AR are mainly expressed in differentiated prostate epithelial cells (Prins et al. 1991). The prolonged passage of the parental cell, which occurred before the immortalization of the HPr-1 cells, may lead to the loss of the more

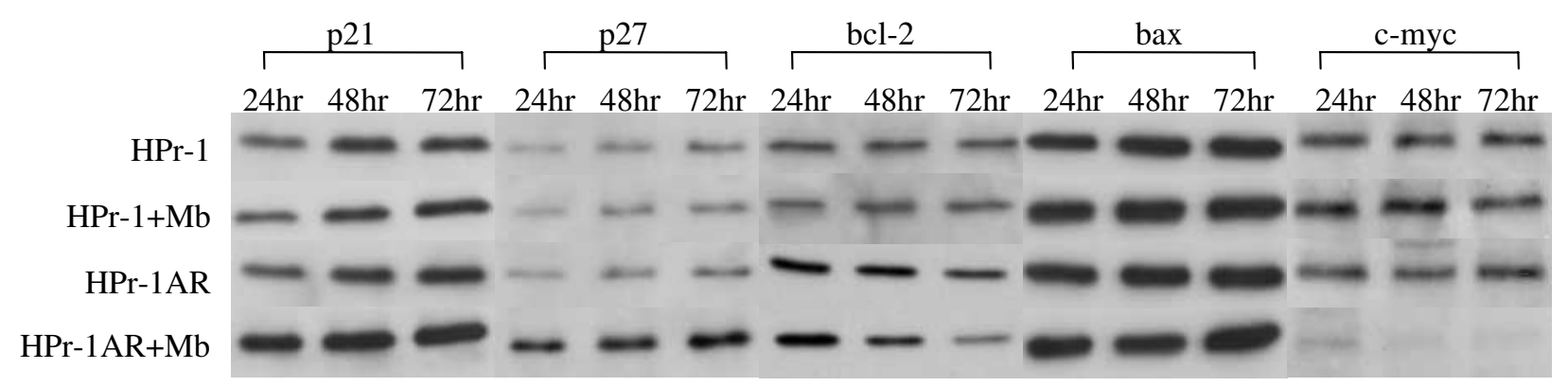

Figure 7 Expression levels of p21, p27, bcl-2, bax and c-myc were modulated by androgen treatment in HPr-1AR cells. Total cell lysates of $\mathrm{HPr}-1 \mathrm{AR}$ cells were obtained after 24, 48 and $96 \mathrm{~h}$ mibolerone $(\mathrm{Mb})$ treatment. An equivalent amount of vehicle was added to the negative controls. Western blot analyses revealed that bcl-2 and c-myc were down-regulated, while p21 and p27 were up-regulated in HPr-1AR cells during androgen treatment. The level of bax remained unchanged during the treatment. 

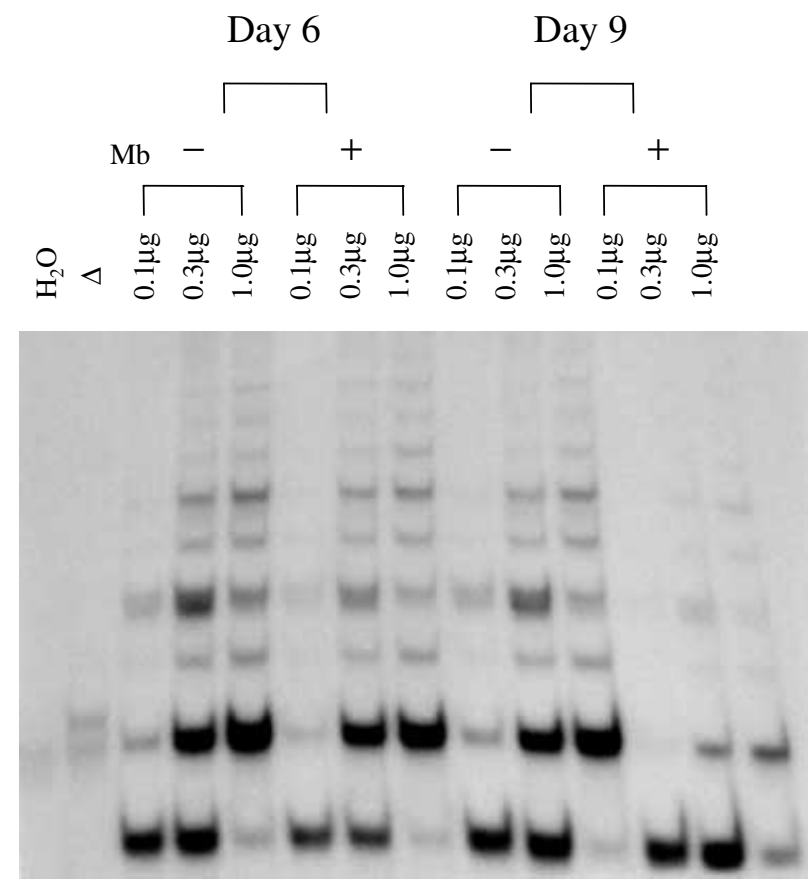

Figure 9 TRAP assay for telomerase activities. Aliquots of each cell extract $(0 \cdot 1,0 \cdot 3$ and $1 \mu \mathrm{g})$ were used for the reaction. A decrease in telomerase activity was observed after 9 days of androgen treatment (mibolerone, $\mathrm{Mb}$ ). Water $\left(\mathrm{H}_{2} \mathrm{O}\right)$ and boiled cell extract $(\Delta)$ served as negative controls.

differentiated AR positive cell, leaving only the less differentiated AR negative cell for immortalization.

Similar to that which Heisler et al. (1997) have shown, expression of the wild-type AR in HPr-1 cells resulted in growth retardation under androgen treatment. However, the androgen-induced apoptosis, which has been observed in PC-3 cells, was not detected in androgen-treated HPr-1AR cells, either by flow cytometry or DNA laddering (data not shown). Apoptosis is known to correlate with differentiation, since cells incapable of differentiation always go through programmed cell death when exposed to differentiation stimulus (Martin et al. 1990, Atencia et al. 1994). HPr-1AR cells differ from PC-3 cells in their non-tumorigenic and apparently normal phenotype. The knowledge that androgen is important for the differentiation of the prostate led us to speculate that androgen might act directly on HPr-1AR cells to stimulate their differentiation, and the induction of apoptosis by androgen on AR-expressing PC-3 cells may be due to the loss of their ability to differentiate upon androgen stimulation. Indeed, the observed changes in HPr-1AR cells treated with androgen agree with our hypothesis.

Morphologically, HPr-1AR cells treated with androgen appeared to undergo differentiation as they became flattened and enlarged, thus resembling epithelial cells undergoing differentiation. Androgen also modulated the expression of cytokeratins and PSA in HPr-1AR cells. The profile of cytokeratin expression is a useful biochemical marker to determine the origin and differentiation status of cells (Moll et al. 1982, Martin et al. 1990). In particular, cytokeratins K8 and K18 have been regarded as tissuespecific and as differentiation markers in prostate epithelial cells (Sherwood et al. 1989, 1991). PSA, on the other hand, is another important biochemical marker of prostate epithelial cells (Sinha et al. 1986, Fong et al. 1991). It is expressed mainly in differentiated secretory cells and is androgen dependent (Wolf et al. 1992, Savoysky et al. 1996). The up-regulation of cytokeratins $\mathrm{K} 8$ and K18, together with the induction of PSA transcript in HPr-1AR cells during androgen treatment provided strong evidence that the cells were undergoing differentiation under the influence of androgen. Although the result from Southern blotting showed that the mRNA level of PSA in HPr$1 \mathrm{AR}$ after six days of androgen treatment is comparable to that of LNCaP, we were unable to detect PSA protein by Western analysis and ELISA with a few of the commercially available PSA antibodies (data not shown). Our suggestion is that the absence of PSA expression is probably due to the incomplete microenvironment in cell culture which is unfavorable to the post-transcriptional processing of PSA.

Cellular differentiation involves the interplay of a concert of gene expression. In our study, we have monitored the expression of $\mathrm{p} 21, \mathrm{p} 27, \mathrm{c}-\mathrm{myc}$ and $\mathrm{bcl}-2$ proteins in response to androgen treatment in $\mathrm{HPr}-1 \mathrm{AR}$ cells. The p21 and p27 proteins are cyclin-dependent kinase inhibitors (CKI) that are involved in the control of the cell cycle, and their induction has been correlated with cell growth arrest and differentiation of various cell lines (Tian \& Quaroni 1999). Western blot analysis indicated that the expression of both p21 and p27 in $\mathrm{HPr}-1 \mathrm{AR}$ cells was modulated by androgen. However, it should be noted that the level of p21 and p27 detected in $\mathrm{HPr}-1$ or the vehicle-treated $\mathrm{HPr}-1 \mathrm{AR}$ cells also increases progressively, presumably due to the increase in contact inhibition as the cells were becoming confluent. Since the androgen-treated $\mathrm{HPr}-1 \mathrm{AR}$ cells remained half confluent at $72 \mathrm{~h}$, the increase in p21 and p27 expression was likely due only to the effect of androgen. A recent study of the promoter of the $\mathrm{p} 21$ gene has identified the presence of an androgen responsive element in the promoter region of the p21 gene ( $\mathrm{Lu}$ et al. 1999), suggesting that p21 may be involved in androgen signaling. It is thus possible that the up-regulation of p21 in $\mathrm{HPr}-1 \mathrm{AR}$ cells is due to transactivation of the $\mathrm{p} 21$ gene by androgen.

The c-myc gene is a proto-oncogene encoding a transcription factor (Grolli et al. 1997) and bcl-2 functions as an inhibitor of apoptosis (Lu et al. 1996). While both c-myc and bcl-2 were down-regulated by androgen in HPr-1AR cells, the drop in c-myc levels was much more drastic. A sharp decline of c-myc levels has also been 
observed in $\mathrm{LNCaP}$ cells that have been induced to differentiate by phorbol 12-myristate 13-acetate (PMA) (Blagosklonny et al. 1997), suggesting that the observed decrease in c-myc expression in HPr-1AR cells might be due to cell differentiation during androgen treatment. The down-regulation of bcl-2 in HPr-1AR cells was less obvious, which might in fact explain the absence of apoptosis following androgen treatment.

Finally, telomerase activity was also found to be modulated in HPr-1AR cells under androgen treatment. Telomerase is a ribonuclear protein that functions as the enzyme for the addition of tandem repeats (TTAGGG)n at the end of chromosomes (Morin 1989). Most of the immortalized cell lines and germ cells are found to be positive for telomerase activity (Kim et al. 1994, Lu et al. 1996). Conversely, telomerase activity has been reported to be absent in terminally differentiated cells (Sharma et al. 1995, Bestilny et al. 1996). We showed that androgen treatment down-regulated telomerase activity in $\mathrm{HPr}-$ $1 \mathrm{AR}$ cells, which was consistent with differentiation of the cells. However, down-regulation of the telomerase activities started only after 9 days of androgen treatment, long after the occurrence of growth arrest and morphological changes. This could possibly be explained by the differentiation status of $\mathrm{HPr}-1 \mathrm{AR}$ cells. In other words, $\mathrm{HPr}-$ $1 \mathrm{AR}$ cells treated with androgen for nine days might have a higher degree of differentiation, so that suppression of telomerase was observed.

It is commonly believed that androgen is essential for the proliferation of prostate epithelial cells, as supported by a number of in vitro models such as $\mathrm{LNCaP}$ (Horoszewicz et al. 1983) or RWPE-1 (Danielpour et al. 1994). In particular, LNCaP cells also show a biphasic response towards androgen (Sonnenschein et al. 1989), with growth stimulated at low concentrations but inhibited at high concentrations of androgen. Interestingly, Geck et al. (1999) have isolated two sub-populations of LNCaP cells that express different levels of AR and respond differently to androgen. For LNCaP cells that express high levels of $\mathrm{AR}$, androgen will induce growth arrest, while in cells that have low levels of AR expression, androgen will stimulate cell growth. Since the AR gene in $\mathrm{LNCaP}$ is mutated, its response to androgen is unpredictable and can be stimulated by androgen antagonists and other steroids (Veldscholte et al. 1992); it is uncertain if the observed response to androgen in $\mathrm{LNCaP}$ also holds true for normal prostate epithelial cells. This highlights the need for a well-characterized and homogenous prostate cell line to properly address the effect of androgen in prostate epithelial cells. The HPr-1AR cell line generated in our laboratory is a well-characterized androgen-responsive non-tumorigenic cell line. We believe that this cell line provides a good model to study androgen effects on normal prostate cell biology. Further genetic manipulation of this cell line may allow for the generation of a step-wise model of prostate cancer development and provide future oppor- tunities to study the effects of androgen on tumorigenic prostate cells.

Androgen ablation is still the first line treatment for prostate cancers, although many patients will eventually suffer from a progression to an androgen independent stage (Scott et al. 1980). Improvements in the current treatment for prostate cancer are urgently needed as the incidence of prostate cancer keeps rising every year and worldwide (Rise et al. 1997). Currently, an intermittent androgen ablation treatment is under clinical trial which, as reported by some of the study groups (Oliver et al. 1997, Rambeaud 1999) has shown beneficial effects to patients by delaying the emergence of hormone independent cancer. It is believed that the withdrawal of androgen blockage at intervals may allow the cancer cells to retain certain degrees of differentiation as well as androgen dependency (Sato et al. 1996). Our finding that androgen can stimulate prostate epithelial cells to differentiate in vitro may form the theoretical basis for the development of new therapies for prostate cancer.

\section{Acknowledgements}

This work was made possible by the CRCG grant 10200376-28299·20600·301·01 from The University of Hong Kong. We thank Ms Vicky Tin for her excellent technical assistance and Dr Christine Suen and Dr Wendy Liu for critical reading of the manuscript and helpful discussions.

\section{References}

Atencia R, Garcia SM, Unda F \& Arechaga J 1994 Apoptosis during retinoic acid-induced differentiation of F9 embryonal carcinoma cells. Experimental Cell Research 214 663-667.

Bello D, Webber MM, Kleinman HK, Wartinger DD \& Rhim JS 1997 Androgen responsive adult human prostatic epithelial cell lines immortalized by human papillomavirus 18. Carcinogenesis $\mathbf{1 8}$ 1215-1223.

Berges RR, Furuya Y, Remington L, English HF, Jacks T \& Isaacs JT 1993 Cell proliferation, DNA repair, and p53 function are not required for programmed death of prostatic glandular cells induced by androgen ablation. PNAS 90 8910-8914.

Berthon P, Waller AS, Villette JM, Loridon L, Cussenot O \& Maitland NJ 1997 Androgens are not a direct requirement for the proliferation of human prostatic epithelium in vitro. International Journal of Cancer 73 910-916.

Bestilny LJ, Brown CB, Miura Y, Robertson LD \& Riabowol KT 1996 Selective inhibition of telomerase activity during terminal differentiation of immortal cell lines. Cancer Research 56 3796-3802.

Blagosklonny MV, Prabhu NS \& El Deiry WS 1997 Defects in p21 WAF1/CIP1, Rb, and c-myc signaling in phorbol ester-resistant cancer cells. Cancer Research 57 320-325.

Blanchere M, Berthaut I, Portois MC, Mestayer C \& Mowszowicz I 1998 Hormonal regulation of the androgen receptor expression in human prostatic cells in culture. Journal of Steroid Biochemistry and Molecular Biology 66 319-326. 
Chodak GW, Kranc DM, Puy LA, Takeda H, Johnson K \& Chang C 1992 Nuclear localization of androgen receptor in heterogeneous samples of normal, hyperplastic and neoplastic human prostate. Journal of Urology 147 798-803.

Choo CK, Ling MT, Chan KW, Tsao SW, Zheng Z, Zhang D, Chan LC \& Wong YC 1999 Immortalization of human prostate epithelial cells by HPV 16 E6/E7 open reading frames. Prostate $\mathbf{4 0}$ 150-158.

Coffey DS 1993 The molecular biology of the prostate. In Prostate Diseases, pp 28-56. Eds H Lepor \& RK Lawson. Philadelphia: W.B. Saunders.

Cunha GR \& Lung B 1978 The possible influence of temporal factors in androgenic responsiveness of urogenital tissue recombinants from wild-type and androgen-insensitive (Tfm) mice. Journal of Experimental Zoology 205 181-193.

Danielpour D, Kadomatsu K, Anzano MA, Smith JM \& Sporn MB 1994 Development and characterization of nontumorigenic and tumorigenic epithelial cell lines from rat dorsal-lateral prostate. Cancer Research 54 3413-3421.

Fong CJ, Sherwood ER, Sutkowski DM, Abu-Jawdeh GM, Yokoo H, Bauer KD, Kozlowski JM \& Lee C 1991 Reconstituted basement membrane promotes morphological and functional differentiation of primary human prostatic epithelial cells. Prostate 19 221-235.

Geck P, Szelei J, Jimenez J, Sonnenschein C \& Soto AM 1999 Early gene expression during androgen-induced inhibition of proliferation of prostate cancer cells: a new suppressor candidate on chromosome 13, in the BRCA2-Rb1 locus. Journal of Steroid Biochemistry and Molecular Biology 68 41-50.

Grant ES, Batchelor KW \& Habib FK 1996 Androgen independence of primary epithelial cultures of the prostate is associated with a down-regulation of androgen receptor gene expression. Prostate 29 339-349.

Grolli S, Accornero P, Ramoni R, Donofrio G \& Whitelaw CB 1997 Expression of c-myc is down-regulated as mouse mammary epithelial cells become confluent. Biochemical and Biophysical Research Communications 239 566-569.

Hayward SW, Dahiya R, Cunha GR, Bartek J, Deshpande N \& Narayan P 1995 Establishment and characterization of an immortalized but non-transformed human prostate epithelial cell line: BPH-1. In Vitro Cellular and Developmental Biology. Animal 31 $14-24$.

Heisler LE, Evangelou A, Lew AM, Trachtenberg J, Elsholtz HP \& Brown TJ 1997 Androgen-dependent cell cycle arrest and apoptotic death in PC-3 prostatic cell cultures expressing a full-length human androgen receptor. Molecular and Cellular Endocrinology 126 59-73.

Horoszewicz JS, Leong SS, Kawinski E, Karr JP, Rosenthal H, Chu TM, Mirand EA \& Murphy GP 1983 LNCaP model of human prostatic carcinoma. Cancer Research 43 1809-1818.

Kaighn ME, Narayan KS, Ohnuki Y, Lechner JF \& Jones LW 1979 Establishment and characterization of a human prostatic carcinoma cell line (PC-3). Investigative Urology 17 16-23.

Kim NW, Piatyszek MA, Prowse KR, Harley CB, West MD, Ho PL, Coviello GM, Wright WE, Weinrich SL \& Shay JW 1994 Specific association of human telomerase activity with immortal cells and cancer [see comments]. Science 266 2011-2015.

Lu QL, Abel P, Foster CS \& Lalani EN 1996 bcl-2: role in epithelial differentiation and oncogenesis. Human Pathology 27 102-110.

Lu S, Liu M, Epner DE, Tsai SY \& Tsai MJ 1999 Androgen regulation of the cyclin-dependent kinase inhibitor p21 gene through an androgen response element in the proximal promoter. Molecular Endocrinology 13 376-384.

McKeehan WL, Adams PS \& Rosser MP 1984 Direct mitogenic effects of insulin, epidermal growth factor, glucocorticoid, cholera toxin, unknown pituitary factors and possibly prolactin, but not androgen, on normal rat prostate epithelial cells in serum-free, primary cell culture. Cancer Research 44 1998-2010.
Martin SJ, Bradley JG \& Cotter TG 1990 HL-60 cells induced to differentiate towards neutrophils subsequently die via apoptosis. Clinical and Experimental Immunology 79 448-453.

Mickey DD, Stone KR, Wunderli H, Mickey GH \& Paulson DF 1980 Characterization of a human prostate adenocarcinoma cell line (DU 145) as a monolayer culture and as a solid tumor in athymic mice. Progress in Clinical and Biological Research 37 67-84.

Miller AD \& Buttimore C 1986 Redesign of retrovirus packaging cell lines to avoid recombination leading to helper virus production. Molecular and Cellular Biology 6 2895-2902.

Moll R, Franke WW, Schiller DL, Geiger B \& Krepler R 1982 The catalog of human cytokeratins: patterns of expression in normal epithelia, tumors and cultured cells. Cell 31 11-24.

Morin GB 1989 The human telomere terminal transferase enzyme is a ribonucleoprotein that synthesizes TTAGGG repeats. Cell $\mathbf{5 9}$ 521-529.

Oliver RT, Williams G, Paris AM \& Blandy JP 1997 Intermittent androgen deprivation after PSA - complete response as a strategy to reduce induction of hormone-resistant prostate cancer. Urology 49 79-82.

Prins GS, Birch L \& Greene GL 1991 Androgen receptor localization in different cell types of the adult rat prostate. Endocrinology 129 3187-3199.

Rambeaud JJ 1999 Intermittent complete androgen blockade in metastatic prostate cancer. European Urology 35 (Suppl 1) 32-36.

Rise LAG, Rosary CL, Hanker BF, Miller BA, Harras A \& Edwards BK (eds) 1997 Statistics Review 1973-1994. (NIHAU pub. no 97-2789). Bethesda, MD: National Cancer Institute.

Rundlett SE, Gordon DA \& Miesfeld RL 1992 Characterization of a panel of rat ventral prostate epithelial cell lines immortalized in the presence or absence of androgens. Experimental Cell Research 203 214-221.

Sato N, Gleave ME, Bruchovsky N, Rennie PS, Goldenberg SL, Lange PH \& Sullivan LD 1996 Intermittent androgen suppression delays progression to androgen-independent regulation of prostate-specific antigen gene in the $\mathrm{LNCaP}$ prostate tumour model. Journal of Steroid Biochemistry and Molecular Biology $\mathbf{5 8}$ 139-146.

Savoysky E, Yoshida K, Ohtomo T, Yamaguchi Y, Akamatsu K, Yamazaki T, Yoshida S \& Tsuchiya M 1996 Down-regulation of telomerase activity is an early event in the differentiation of HL60 cells. Biochemical and Biophysical Research Communications 226 329-334

Scott WW, Menon M \& Walsh PC 1980 Hormonal therapy of prostatic cancer. Cancer 45 1929-1936.

Sharma HW, Sokoloski JA, Perez JR, Maltese JY, Sartorelli AC, Stein CA, Nichols G, Khaled Z, Telang NT \& Narayanan R 1995 Differentiation of immortal cells inhibits telomerase activity. PNAS 92 12343-12346.

Sherwood ER, Berg LA, McEwan RN, Pasciak RM, Kozlowski JM \& Lee C 1989 Two-dimensional protein profiles of cultured stromal and epithelial cells from hyperplastic human prostate. Journal of Cellular Biochemistry 40 201-214.

Sherwood ER, Theyer G, Steiner G, Berg LA, Kozlowski JM \& Lee C 1991 Differential expression of specific cytokeratin polypeptides in the basal and luminal epithelia of the human prostate. Prostate $\mathbf{1 8}$ 303-314.

Sinha AA, Hagen KA, Sibley RK, Wilson MJ, Limas C, Reddy PK, Blackard CE \& Gleason DF 1986 Analysis of fixation effects on immunohistochemical localization of prostatic specific antigen in human prostate. Journal of Urology 136 722-727.

Sonnenschein C, Olea N, Pasanen ME \& Soto AM 1989 Negative controls of cell proliferation: human prostate cancer cells and androgens. Cancer Research 49 3474-3481.

Tian JQ \& Quaroni A 1999 Involvement of p21(WAF1/Cip1) and p27(Kip1) in intestinal epithelial cell differentiation. American Journal of Physiology 276 C1245-C1258. 
Veldscholte J, Berrevoets CA, Ris SC, Kuiper GG, Jenster G, Trapman J, Brinkmann AO \& Mulder E 1992 The androgen receptor in $\mathrm{LNCaP}$ cells contains a mutation in the ligand binding domain which affects steroid binding characteristics and response to antiandrogens. Journal of Steroid Biochemistry and Molecular Biology 41 665-669.
Wolf DA, Schulz P \& Fittler F 1992 Transcriptional regulation of prostate kallikrein-like genes by androgen. Molecular Endocrinology 6 753-762.

Received in final form 21 February 2001 Accepted 1 March 2001 